\title{
Economic losses due to important diseases of bovines in central India
}

\author{
Dhananjay Singh ${ }^{1}$, Sanjay Kumar $^{2}$, B. Singh ${ }^{1}$ and D. Bardhan ${ }^{1}$ \\ 1. Division of Livestock Economics, Statistics and Information Technology, Indian Veterinary Research Institute, \\ Izatnagar - 243 122, Uttar Pradesh, India; 2. ARIS Cell/Computer Centre, Indian Veterinary Research Institute, \\ Izatnagar - 243 122, Uttar Pradesh, India \\ Corresponding author: Dhananjay Singh, email: drruchids@gmail.com \\ SK: sanju01@rediffmail.com, BS: bsingh@ivri.res.in, DB: dwaipayanbardhan@gmail.com \\ Received: 18-03-2014, Revised: 27-06-2014, Accepted: 03-07-2014, Published online: 09-08-2014
}

doi: $10.14202 /$ vetworld.2014.579-585

How to cite this article: Singh D, Kumar S, Singh B and Bardhan D (2014) Economic losses due to important diseases of bovines in central India, Veterinary World 7(8): 579-585.

\begin{abstract}
Aim: To analyze the factors associated with morbidity and mortality rates as well as to evaluate economic losses due to important diseases of bovines, viz. mastitis, haemorrhagic septicaemia (HS) and surra in Purvanchal Region of Uttar Pradesh.

Materials and Methods: A sample of 300 livestock owners were selected from each of five divisions of Purvanchal region of the state of Uttar Pradesh using multistage stratified sampling with simple random sampling without replacement at village level. The morbidity, mortality and case fatality rates due to different diseases were determined using standard statistical indices. Association between cattle morbidity and mortality rates and different factors was calculated by $\chi^{2}$ Test. The total economic loss due to diseases in bovines was worked out as sum of mortality loss, loss in milk yield and cost of treatment of affected animals.

Results: The overall morbidity rates of mastitis, HS and surra in cattle and buffaloes were $15.5 \%, 7.1 \%$ and $5.3 \%$, respectively. The mortality and case fatality due to HS was found higher in the young calves as compared to the adults in case of both buffaloes and cattle. Mortality and case fatality due to surra was greater in the adult animals as compared to the younger ones in case of both buffaloes and cattle. Total losses due to mastitis per lactation in nondescript (ND) cow, crossbred (CB) cow and buffalo were INR 868.34, INR 1, 314.10 and INR 1, 272.36, respectively. Total losses due to HS per animal in ND cows, CB cows and buffaloes were INR 2, 355.78, INR 3, 228.52 and INR 4, 262.57, respectively. Total losses due to surra per animal in ND cow, CB cow and buffalo were INR 3, 328.18, INR 6, 193 and INR 9, 872.33, respectively.
\end{abstract}

Conclusion: The study thus revealed significant losses due to diseases in large ruminants on. There is thus ample scope for preventive measures to control the disease bovines.

Keywords: buffalo, cattle, disease impact, morbidity, mortality.

\section{Introduction}

Disease acts as a negative influence on the livestock production system, thus setting off a cascading affect of low production, low income, and subsistent livelihood. The consequences of animal diseases in livestock can be complex and generally go well beyond the immediate effects on affected producers. These diseases have numerous impacts, including productivity losses for the livestock sector (viz. production losses, cost of treatment, market disturbances), loss of income from activities using animal resources (viz. energy, transportation, tourism), prevention or control costs (production costs, public expenditure) and suboptimal use of production potential (animal species, genetics, livestock practices) [1].

Highly contagious livestock diseases such as foot and mouth disease (FMD), hemorrhagic septicemia (HS), mastitis, peste des petits ruminant (PPR) and surra in cloven footed domestic animals cause irreparable economic losses to the farming community. They also occupy the top position among the livestock diseases

Copyright: The authors. This article is an open access article licensed under the terms of the Creative Commons Attribution License (http://creativecommons.org/licenses/by/2.0) which permits unrestricted use, distribution and reproduction in any medium, provided the work is properly cited.

Veterinary World, EISSN: 2231-0916 due to wide host range, plurality of immunological types, short duration of immunity and economic losses and their impact on livestock production and productivity.

In the above context, a comprehensive economic assessment of animal diseases is of utmost importance before formulating the various livestock health intervention efforts. Several studies in the Indian context are available on the prevalence of major livestock diseases and the economic loss due these diseases [2-11]. However, scant literature is available on economic implications of important diseases based on data from the field level. The risk factor and impact of husbandry practices on occurrence and spread of outbreak have also not been well defined in these studies. A better understanding of the epidemiological and economic parameters elated to important diseases is the need of the day.

The present study was undertaken to assess the status and economic impact of important diseases on production parameters in bovines in India with the following specific objectives:

i. To analyze the socio economic factors associated with the occurrence of important diseases in Bovines. ii. To estimate the economic losses due to important livestock diseases in bovines. 


\section{Materials and Methods}

Sampling and data: The study was carried out in the state of Uttar Pradesh which is the most populous state in India with a population of $199,581,477$ million people [12]. The state covers a large part of the densely populated Gangetic plain consisting of 75 districts, which are grouped into 18 divisions. The study was carried out in the Purvanchal region, which lies at the eastern end of the state comprising of five divisions viz. Gorakhpur (latitude $26.76^{\circ} \mathrm{N}$ and longitude $83.36^{\circ} \mathrm{E}$ ), Mirzapur (latitude $25.15^{\circ} \mathrm{N}$ and longitude $82.6^{\circ} \mathrm{E}$ ), Varanasi (latitude $25.28^{\circ} \mathrm{N}$ and longitude $82.95^{\circ} \mathrm{E}$ ), Basti (latitude $27.25^{\circ} \mathrm{N}$ and longitude $83.00^{\circ} \mathrm{E}$ ) and Azamgarh (latitude $26.6^{\circ} \mathrm{N}$ and longitude $83.19^{\circ} \mathrm{E}$ ), which together comprises of 17 districts. Stratified multistage random sampling was used in the study. One district was selected from each of the five divisions and two blocks were selected from each of the selected district, randomly. From each selected block, two villages were selected, randomly. Thus, the sample for the study comprised of 5 districts, 10 blocks and 20 villages. On the basis of a pre-survey, a list of farmers having at least two adult cattle or buffaloes, were prepared from each selected village. Then, simple random sampling without replacement was followed to select 15 livestock owners/households from that list. Thus, 300 livestock owners/households constituted the ultimate sampling units for the study.

Data were collected from a primary field survey of the selected households by personally interviewing the household heads with the help of a comprehensive and pre-tested questionnaire specifically designed for the study. Data pertaining to incidence of specific diseases were collected on the basis of farmers' recall for the reference period. The interviewer, being a veterinarian, the specific diseases that affected animals were identified by the standard symptoms as elicited by the livestock owner. The identification of diseases was then further corroborated with the local veterinarian who was already in the knowledge in regard to outbreak areas of the diseases and livestock owners whose animals have been affected by such outbreaks.

Apart from data on incidence of diseases, data were also collected on socio-economic and farm characteristics of the households, production parameters, components of economic losses due to diseases, viz. productive and reproductive losses, costs incurred in control/treatment and opportunity costs. The data collected pertained to the period January, 2011 to December, 2011.

Analytical framework: The morbidity, mortality and case fatality rates due to different diseases were determined using standard statistical indices. For estimation of mortality and morbidity rates in bovines, the population at risk was taken as mid-year population i.e. June 2011 population. Formulae used for mortality and morbidity rates and case fatality rates were: Morbidity Rate $(\%)=[$ No. of cases observed during study period/ Population (mid year) ] X 100
Mortality Rate $(\%)=[$ No. of deaths observed during study period/ Population (mid year) ] x 100

Case fatality rate $(\%)=[$ No. of animals died during study period / No. of cases of diseases during study period] x 100

Association between cattle morbidity and mortality rates and different factors was calculated by $\chi 2$ Test.

Estimation of economic losses due to diseases: The total economic loss due to diseases in bovines was worked out as sum of (A) mortality loss, (B) loss in milk yield and $(\mathrm{C})$ cost of treatment of affected animals.

The total economic loss is expressed as

$\mathrm{T}_{\mathrm{L}}=\mathrm{A}+\mathrm{B}+\mathrm{C}$

A. Loss from mortality: This was worked out as the product of number of died animals (D) due to the disease and probable market value $(\mathrm{P})$ of the animal.

$\mathrm{A}=\mathrm{D} \times \mathrm{P}$

B. Loss in milk yield: $B=B_{1}+B_{2}+B_{3}$

$B_{1}=$ Value of direct loss due to reduction in milk yield: For the proportion of cows in milk in the herd, the losses were expressed in terms of reduction in milk yield, which through the price of milk could be directly converted into monetary terms. When a cow died as a result of the disease, the adopted market value was assumed to reflect its production worth. The double counting or costing was avoided. The immediate fall in milk production in lactating cows is never gained later and therefore, constituted a significant loss.

The loss due to direct decline in milk production was estimated using formula:

$\mathrm{B}_{1}=(\mathrm{I}-\mathrm{D}) \mathrm{P}_{1} \mathrm{~L}$ Z M

Where, $\mathrm{I}=$ Number of infected animals

$\mathrm{D}=$ Number of animals died

$\mathrm{P}_{1}=$ Proportion of animals in milk

$\mathrm{Z}=$ Annual average milk yield per milch animal

$\mathrm{L}=$ Proportion of lactation lost

$\mathrm{M}=$ Price of milk

$B_{2}=$ Loss of milk due to increased abortion: Abortion can occur due to specific disease, particularly in the late pregnancies and leads to increased calving index, besides loss of calf. Assuming the time for abortion as 8 months from conception, and a delay of six months in the next conception, the calving index gets increased by 13.5 months in aborting cases, and the milk loss due to increased abortions were estimated from equation: $\mathrm{B}_{2}=\left[\left(12 / \mathrm{C}_{1}\right)-\left\{12 /\left(\mathrm{C}_{1}+13.5 \mathrm{~A}\right)\right\}\right](\mathrm{I}-\mathrm{D}) \mathrm{P}_{1} \mathrm{Y} \mathrm{M}$

Where, $\mathrm{C}_{1}=$ Calving Index

$\mathrm{A}=$ Increased abortion rate

$\mathrm{Y}=$ Average lactation yield per milch animal

$B_{3}=$ Milk loss due to increased inter-calving period: The problem of non-conception caused by a disease increases the inter-calving period and thus lower number of animals will be in milk at any given time. As a result of non-conception or delayed conception, the milk output gets reduced. An average delay of 3 months in the next conception was assumed for all the animals affected by the disease. The loss of milk was calculated by the reduction in proportion of lactating animals in any year multiplied by the average milk yield per in- 
Table-1: Morbidity rates of various diseases $\left(\chi^{2}=5.58\right)$.

\begin{tabular}{|c|c|c|c|c|c|c|c|c|c|c|c|c|}
\hline \multirow[t]{2}{*}{ Disease } & \multicolumn{2}{|c|}{ Varanasi } & \multicolumn{2}{|c|}{ Azamgarh } & \multicolumn{2}{|c|}{ Basti } & \multicolumn{2}{|c|}{ Gorakhpur } & \multicolumn{2}{|c|}{ Mirzapur } & \multicolumn{2}{|c|}{ Total } \\
\hline & No. & $\%$ & No. & $\%$ & No. & $\%$ & No. & $\%$ & No. & $\%$ & No. & $\%$ \\
\hline Mastitis & 13 & 14.60 & 11 & 14.4 & 12 & 15.7 & 10 & 16.1 & 7 & 17.5 & 53 & 15.5 \\
\hline & 23 & 7.5 & 24 & 8.4 & 19 & 6.6 & 16 & 6 & 17 & 6.7 & 99 & 7.1 \\
\hline Surra & 13 & 4.2 & 14 & 5 & 16 & 5.5 & 17 & 6.4 & 15 & 6 & 75 & 5.3 \\
\hline
\end{tabular}

Table-2: Species specific morbidity rates $\left(\chi^{2}=18.168 * *\right)$.

\begin{tabular}{lllllllll}
\hline \multirow{2}{*}{ Disease } & \multicolumn{2}{c}{ Cattle } & & \multicolumn{2}{c}{ Buffalo } & & \multicolumn{2}{c}{ Total } \\
\cline { 2 - 3 } \cline { 8 - 9 } \cline { 7 - 8 } & No. & $\%$ & & No. & $\%$ & & No. & $\%$ \\
\hline Mastitis & 34 & 18 & & 19 & 12.3 & & 53 & 15.5 \\
HS & 35 & 4.5 & & 64 & 10 & & 99 & 7.1 \\
Surra & 45 & 6 & & 30 & 4.7 & & 75 & 5.3 \\
\hline
\end{tabular}

** Significant at $5 \%$ level of significance

Table-3: Breed specific morbidity rates in cattle $\left(\chi^{2}=9.7 *\right)$.

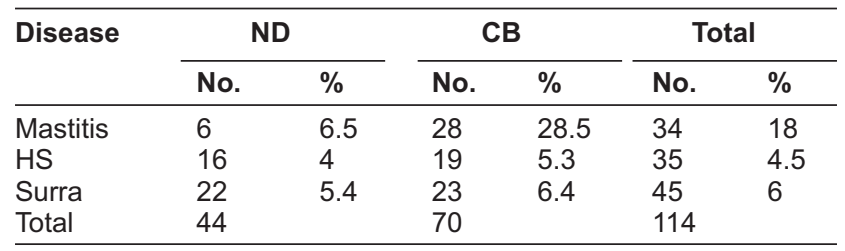

*Significant at $5 \%$ level of significance

Table-4: Sex specific morbidity rates in cattle and buffalo $\left(\chi 2=29.05^{* *}\right)$.

\begin{tabular}{|c|c|c|c|c|c|c|c|c|}
\hline \multirow[t]{3}{*}{ Disease } & \multicolumn{4}{|c|}{ Cattle } & \multicolumn{4}{|c|}{ Buffalo } \\
\hline & \multicolumn{2}{|c|}{ Male } & \multicolumn{2}{|c|}{ Female } & \multicolumn{2}{|c|}{ Male } & \multicolumn{2}{|c|}{ Female } \\
\hline & No. & $\%$ & No. & $\%$ & No. & $\%$ & No. & $\%$ \\
\hline Mastitis & 0 & 0 & 34 & 18 & - & - & 19 & \\
\hline HS & 12 & 6 & 23 & 4 & 32 & 5 & 32 & 5 \\
\hline Surra & 13 & 6.5 & 32 & 5.6 & - & - & 30 & 4.7 \\
\hline Total & 25 & & 89 & & 32 & & 81 & \\
\hline
\end{tabular}

** Significant at $5 \%$ level of significance

Table-5: Age specific morbidity rates in cattle and buffalo $\left(\chi 2=65.1^{* *}\right.$ (Cattle) $\chi 2=90.73 * *$ (Buffalo).

\begin{tabular}{|c|c|c|c|c|c|c|c|c|c|c|c|c|}
\hline \multirow[t]{3}{*}{ Disease } & \multicolumn{6}{|c|}{ Cattle } & \multicolumn{6}{|c|}{ Buffalo } \\
\hline & \multicolumn{2}{|c|}{ Calf } & \multicolumn{2}{|c|}{ Young } & \multicolumn{2}{|c|}{ Adult } & \multicolumn{2}{|c|}{ Calf } & \multicolumn{2}{|c|}{ Young } & \multicolumn{2}{|c|}{ Adult } \\
\hline & No. & $\%$ & No. & $\%$ & No. & $\%$ & No. & $\%$ & No. & $\%$ & No. & $\%$ \\
\hline Mastitis & 0 & 0 & 0 & 0 & 34 & 18 & - & - & - & - & 19 & 12.3 \\
\hline $\mathrm{HS}$ & 14 & 7.5 & 6 & 3.7 & 15 & 3.5 & 36 & 23.84 & 14 & 8 & 14 & 4.6 \\
\hline Surra & 1 & .53 & 4 & 2.5 & 40 & 9.5 & - & - & 7 & 4 & 23 & 7.5 \\
\hline Total & 15 & & 10 & & 89 & & 36 & & 21 & & 56 & \\
\hline
\end{tabular}

milk bovine per year and by the price $\mathrm{M}$.

$\mathrm{B}_{3}=\left[\left(12 / \mathrm{C}_{1}\right)-\left\{12 /\left(\mathrm{C}_{1}+3\right)\right\}\right](\mathrm{I}-\mathrm{D}) \mathrm{P}_{1} \mathrm{Y} M$

C. Treatment costs

$\mathrm{C}=\mathrm{I} \mathrm{T}_{\mathrm{C}}$, Where, $\mathrm{T}_{\mathrm{C}}=$ Average treatment cost of an infected animal (INR)

\section{Results and Discussion}

Morbidity rates of various diseases: The overall morbidity rates of mastitis, HS and surra in cattle and buffaloes were $15.5 \%, 7.1 \%$ and $5.3 \%$ respectively (Table-1). Chi square test statistic $(\chi 2)$ revealed lack of significant difference $(\mathrm{P}>0.05)$ between morbidity rates in different districts in the region. Prevalence rate of mastitis as reported from Tamil Nadu was 12.93 and $13.09 \%$ in case of cows and 7.04 and $7.72 \%$ in case of buffaloes in government/university farms and private farms, respectively [13]. Singh [14] reported that incidence rate of mastitis in crossbred cows in an organised dairy farm varied between 22.31 and 62.54 $\%$ during various years of the period 2002-2005. Findings regarding overall morbidity rates of HS are in agreement with that of earlier studies $[3,15]$.

The morbidity rates of mastitis, HS and surra in cattle were $18 \%, 4.5 \%$ and $6 \%$, respectively (Table-2). The morbidity rates in buffaloes for the above diseases in the same order were $12.3 \%, 10 \%$ and $4.7 \%$, respectively. Chi square analysis revealed significant difference $(\mathrm{P}>0.05)$ in morbidity rates between cattle and buffaloes. Incidence of mastitis was higher in cows $(18 \%)$ than in buffaloes $(12.3 \%)$. Higher incidence rates of mastitis in cows than in buffaloes were also reported in many earlier studies [4, 13]. Higher morbidity rates of HS in buffaloes as compared to cattle as observed in this study are in consonance with the findings of earlier studies [16-20].

The morbidity rates of mastitis, HS and surra in nondescript (ND) cattle were $6.5 \%, 4 \%$ and $5.4 \%$, respectively and the corresponding figures in case of crossbred (CB) cows were $28.5 \%, 5.3 \%$ and $6.4 \%$, respectively (Table-3). Chi square test statistic $(\chi 2)$ revealed significant difference $(\mathrm{P}>0.05)$ in morbidity rates between $\mathrm{ND}$ and $\mathrm{CB}$ cattle. The high morbidity rates of various diseases in CB cattle than ND cattle might be due to more resistant power against diseases in the latter breed of animals.

The morbidity rates in male cattle were more in case of HS $(6 \%)$ and surra $(6.5 \%)$ than in female cattle ( $4 \%$ and $5.6 \%$, respectively). Chi-square analysis showed that the morbidity pattern differed significantly $(p<0.01)$ between male and female animals (Table-4). In case of 
Table-6: Mortality rate/CFR of HS

\begin{tabular}{|c|c|c|c|c|c|c|c|c|c|c|c|c|c|c|c|}
\hline \multirow[t]{2}{*}{ Spp/Breed } & \multicolumn{3}{|c|}{ No. of animal } & \multicolumn{3}{|c|}{ No. of infected } & \multicolumn{3}{|c|}{ No. of died } & \multicolumn{3}{|c|}{ Mortality Rate (\%) } & \multicolumn{3}{|c|}{ CFR(\%) } \\
\hline & (1) & (2) & (3) & (1) & (2) & (3) & (1) & (2) & (3) & (1) & (2) & (3) & (1) & (2) & (3) \\
\hline Cattle(ND) & 92 & 72 & 240 & 6 & 2 & 8 & 5 & 1 & 3 & 5.4 & 1.3 & 1.25 & 83.3 & 50 & 37.5 \\
\hline Cattle(CB) & 94 & 87 & 177 & 8 & 4 & 7 & 6 & 3 & 2 & 6.3 & 3.4 & 1.1 & 75 & 75 & 28.5 \\
\hline Buffalo & 151 & 176 & 303 & 36 & 14 & 14 & 30 & 10 & 5 & 20 & 5.7 & 1.7 & 84 & 72 & 35.7 \\
\hline Total & 337 & 335 & 720 & 50 & 20 & 29 & 41 & 14 & 10 & 12.8 & 4.1 & 1.3 & 82 & 70 & 34.4 \\
\hline
\end{tabular}

(1) Calves (2) Young one (3) Adult

Table-7: Mortality rate/CFR of Surra.

\begin{tabular}{|c|c|c|c|c|c|c|c|c|c|c|c|c|c|c|c|}
\hline \multirow[t]{2}{*}{ Spp/Breed } & \multicolumn{3}{|c|}{ No. of animal } & \multicolumn{3}{|c|}{ No. of infected } & \multicolumn{3}{|c|}{ No. of died } & \multicolumn{3}{|c|}{ Mortality Rate (\%) } & \multicolumn{3}{|c|}{ CFR(\%) } \\
\hline & $(1)$ & (2) & (3) & $(1)$ & (2) & (3) & (1) & (2) & (3) & (1) & $(2)$ & (3) & (1) & (2) & (3) \\
\hline Cattle(ND) & 92 & 72 & 240 & 1 & 0 & 21 & 1 & 0 & 4 & 1.08 & 0 & 1.67 & 100 & 0 & 19 \\
\hline Cattle(CB) & 94 & 87 & 177 & 0 & 4 & 19 & 0 & 2 & 3 & 0 & 2.2 & 1.6 & 0 & 50 & 15.7 \\
\hline Buffalo & 151 & 176 & 303 & 0 & 7 & 23 & 0 & 2 & 6 & 0 & 1.2 & 2 & 0 & 28.5 & 26 \\
\hline Total & 337 & 335 & 720 & 1 & 11 & 63 & 1 & 4 & 13 & .67 & 1.2 & 1.8 & 100 & 37 & 21 \\
\hline
\end{tabular}

(1) Calves (2) Young one (3) Adult

Table-8: Total economic losses due to mastitis. (INR)

\begin{tabular}{lcccccc}
\hline Spp/Breed & No. of cases & $\begin{array}{c}\text { Yield loss } \\
\text { (A) (Rs) }\end{array}$ & $\begin{array}{c}\text { Discarded milk } \\
\text { (B) (Rs) }\end{array}$ & $\begin{array}{c}\text { Production loss } \\
\text { (A+B) (Rs) }\end{array}$ & $\begin{array}{c}\text { Treatment cost } \\
\text { (Rs) }\end{array}$ & $\begin{array}{c}\text { Total loss } \\
\text { (Rs) }\end{array}$ \\
\hline ND Cows & 6 & 1900 & 160 & 2060 & 3150 & 5210 \\
CB cows & 28 & 15300 & 2020 & 17320 & 19475 & 36795 \\
Buffaloes & 19 & 10500 & 1375 & 11875 & 12300 & 24175 \\
Total & 53 & 27700 & 3555 & 31255 & 34925 & 66180 \\
\hline
\end{tabular}

buffaloes, male and female animals were affected equally by HS (5\%). The incidence of surra was found only in female buffaloes $(4.7 \%)$.

Chi-square analysis showed significant difference $(p<0.01)$ in rates of morbidity in different age groups in case of cattle (Table-5). Out of total cattle morbidity, calves were highly affected $(7.5 \%)$ by HS than young $(3.7 \%)$ and adult $(3.5 \%)$ animals. Surra was more prevalent in adult $(9.5 \%)$ than in young animals $(2.5 \%)$ and calves $(0.53 \%)$. Mastitis occurred only in adult animals. In case of buffaloes also, significant difference $(p<0.01)$ in rates of morbidity in different age groups was observed. The calves were highly affected by HS $(23.8 \%)$, as against to young stocks $(8 \%)$ and adult animals $(4.6 \%)$. High morbidity rates of HS in calves as observed in this study are in consonance with the findings of Farooq et al. [20]. Surra were more prevalent in adult animals (7.5\%) than in young animals (4\%) and calves.

Mortality rates of various diseases: Mortality was not found in case of mastitis. The overall mortality due to diseases was more in buffaloes than in cattle. Similar results were reported by de Alwis [17]. In case of HS, in young buffalo calves, mortality rate and case fatality rates were $20 \%$, and $84 \%$, respectively (Table-6). In adult buffaloes, mortality and case fatality rates were $1.7 \%$, and $35.7 \%$, respectively. In case of young ND cattle calves, mortality and case fatality rates were $5.44 \%$, and $83.3 \%$, respectively. In case of ND adult cattle, mortality and case fatality rates were recorded as $1.25 \%$, and $37.5 \%$, respectively. In case of CB cattle calves, mortality and case fatality rates were $6.3 \%$, and $75 \%$, respectively. In case of CB adult cattle, mortality and case fatality rates were recorded as $1.1 \%$, and $28.5 \%$, respectively. The higher mortality and case fatality due to HS in the young calves as compared to the adults in case of both buffaloes and cattle as observed in this study are in consonance with the findings of earlier studies $[18,19,20]$.

Mortality and case fatality due to Trypanosomiasis (surra) was greater in adult animals as compared to the young ones in case of both buffaloes and cattle (Table-7). In young buffalo calves, no mortality was observed. In adult buffaloes, mortality and case fatality rates were $2 \%$, and $26 \%$, respectively. In case of ND adult cattle, mortality and case fatality rates were $1.67 \%$, and $19 \%$, respectively. In case of CB adult cattle, mortality and case fatality rates were $1.6 \%$, and $15.7 \%$, respectively.

\section{Economic losses due to diseases}

Economic losses due to mastitis: Total economic loss was INR 5, 210 in ND cattle, INR 36, 795 in CB cattle and INR 24, 175 in buffalo (Table-8). Economic loss per animal per lactation was INR 868, INR 1314 and INR 1272 in case of ND cattle, CB cattle and buffaloes, respectively (Table-9). Sasidhar et al. [21] had reported from an organized dairy farm in Hyderabad a loss of INR 326 per infected cow due to mastitis. Thirunavukkarasu and Prabaharan [13] had reported that total loss in affected crossbred cows and buffaloes were INR 536.25 and INR 404.73 per lactation, respectively. Bardhan [22] had reported average loss due to mastitis per animal per month to be INR 3206.55, INR 2119.67 and INR 1708.89 in optimistic scenario and INR 3549.59, INR 2448.03 and INR 1934.78 in pessimistic scenario in case of CB cows, indigenous cows and buffaloes, respectively. The value of economic loss due to mastitis as reported by Bardhan [22] was higher as replacement cost was also included in the total cost of mastitis in addition to production loss and treatment cost. 
Table-9: Economic losses per animal per lactation in mastitis. (INR)

\begin{tabular}{lccccc}
\hline Spp/Breed & $\begin{array}{c}\text { Yield loss } \\
\text { (A) (Rs) }\end{array}$ & $\begin{array}{c}\text { Discarded milk } \\
\text { (B) (Rs) }\end{array}$ & $\begin{array}{c}\text { Production loss } \\
\text { (A+B) (Rs) }\end{array}$ & $\begin{array}{c}\text { Treatment cost } \\
\text { (Rs) }\end{array}$ & $\begin{array}{c}\text { Total loss } \\
\text { (Rs) }\end{array}$ \\
\hline ND Cows & $316.67(92.23)^{\mathrm{a}}$ & $26.67(7.76)^{\mathrm{a}}$ & $343.34(39.53)^{\mathrm{b}}$ & $525(60.46)^{\mathrm{b}}$ & 868.34 \\
CB cows & $546.42(88.33)^{\mathrm{a}}$ & $72.14(11.66)^{\mathrm{a}}$ & $618.56(47.07)^{\mathrm{b}}$ & $695.53(52.92)^{\mathrm{b}}$ & 1314.1 \\
Buffaloes & $552.63(88.42)^{\mathrm{a}}$ & $72.36(11.57)^{\mathrm{a}}$ & $625(49.12)^{\mathrm{b}}$ & $647.36(50.87)^{\mathrm{b}}$ & 1272.36 \\
Total & $522.64(88.62)^{\mathrm{a}}$ & $67.07(11.37)^{\mathrm{a}}$ & $589.71(47.22)^{\mathrm{b}}$ & $658.96(52.78)^{\mathrm{b}}$ & 1248.67 \\
\hline
\end{tabular}

(a: figures in parentheses indicates percentage to production losses), (b: figures in parentheses indicates percentage to total losses).

Table-10: Mortality losses due to HS. (INR)

\begin{tabular}{lcccccc}
\hline Spp/Breed & $\begin{array}{c}\text { Total No. } \\
\text { of died }\end{array}$ & $\begin{array}{c}\text { Mortality of } \\
\text { calves(Rs) }\end{array}$ & $\begin{array}{c}\text { Mortality of } \\
\text { young one (Rs) }\end{array}$ & $\begin{array}{c}\text { Mortality of } \\
\text { adult animal }\end{array}$ & $\begin{array}{c}\text { Treatment cost } \\
\text { (Rs) }\end{array}$ & $\begin{array}{c}\text { Total loss } \\
\text { (Rs) }\end{array}$ \\
\hline ND Cows & 8 & $6000(18)$ & $10000(30)$ & $15000(45)$ & $2350(7)$ & 33350 \\
CB cows & 12 & $8500(14.9)$ & $15000(26.4)$ & $30000(52.8)$ & $3250(5.72)$ & 56750 \\
Buffaloes & 48 & $45000(17.2)$ & $105500(40.4)$ & $100000(38.3)$ & $10550(4.1)$ & 261050 \\
Total & 68 & $59500(16.9)$ & $130500(37.1)$ & $145000(41.29)$ & $16150(4.5)$ & 351150 \\
\hline
\end{tabular}

Figures in brackets indicate percentages to the total loss.

Table-11: Morbidity losses due to HS. (INR)

\begin{tabular}{lccccc}
\hline Spp/Breed & $\begin{array}{c}\text { Total No. of } \\
\text { recovered }\end{array}$ & $\begin{array}{c}\text { No. of lactating } \\
\text { animal }\end{array}$ & $\begin{array}{c}\text { Total milk loss } \\
\text { (Rs) }\end{array}$ & $\begin{array}{c}\text { Treatment cost } \\
\text { (Rs) }\end{array}$ & $\begin{array}{c}\text { Total loss } \\
\text { (Rs) }\end{array}$ \\
\hline ND Cows & 8 & 6 & $892.5(20.5)$ & $3450(79.4)$ & 4342.5 \\
CB cows & 7 & 3 & $792(17.2)$ & $3800(82.7)$ & 4592 \\
Buffaloes & 16 & 7 & $4255(36.19)$ & $7500(63.8)$ & 11755 \\
Total & 31 & 16 & $5939.5(28.7)$ & $14750(71.29)$ & 20689.5 \\
\hline
\end{tabular}

Figures in brackets indicate percentages to the total loss.

The major part of the loss in lactating animal suffering from mastitis was due to cost of treatment. In case of ND cows it was found out to be INR 525 whose share was $60.46 \%$ t out of the total loss (Table-9). The same figure in case of CB cows was INR 695.53 which was $52.92 \% \mathrm{t}$ of the total loss. In case of buffaloes the major contribution to the total loss was also cost of treatment at INR 647.36 (50.87\% of total loss). The next major component of loss was production loss which included milk yield loss and discarded milk loss. In ND cows, production loss accounted for $39.53 \%$ of total loss. Yield loss and discarded milk loss was INR 316.67 and INR 26.67, which constituted $92.23 \%$ and $7.76 \%$ of production loss, respectively. In CB cows, production loss accounted for INR 618.56 which was $47.07 \%$ of total loss. Yield loss and discarded milk loss was INR 546.42 and INR 72.14, respectively, which was $88.33 \%$ and $11.66 \%$ of production loss, respectively. In buffaloes, production loss accounted for INR 625 and its share was $49.12 \%$ of total loss. Yield loss and discarded milk loss was INR 552.63 and Rs 72.36 , which constituted $88.42 \%$ and $11.57 \%$ of production loss, respectively. Ozsvari et al. [23] had reported that production loss due to mastitis per infected animal accounts for $59 \%$ of total loss.

Economic losses due to HS: Mortality losses due to HS in Nondescript cattle were INR 33, 350, in which share of mortality of calves, young ones and adult animals were $18 \%, 30 \%$ and $45 \%$, respectively (Table-10). Treatment cost constituted $7 \%$ of total loss. In case of CB cattle, mortality losses were INR 56, 750 in which share of mortality of calves, young ones, adult animals and treatment cost constituted $14.9 \%, 26.4 \%, 52.8 \%$ and $5.72 \%$, respectively. Mortality losses due to HS in case of buffaloes were INR 2, 61, 050, in which percentage contribution of calves, young ones, adult animals and cost of treatment were $17.2 \%, 40.4 \%, 38.3 \%$ and $4.1 \%$, respectively.

Morbidity loss due to HS in ND cattle was INR 4, 342.50 , in which share of yield loss and treatment costs were $20.5 \%$ and $79.4 \%$, respectively. In case of CB cattle, morbidity losses were INR 4, 592 in which share of yield loss and treatment costs were $17.2 \%$ and $82.7 \%$, respectively. Morbidity losses in buffaloes were INR 11,755 , in which $36.19 \%$ was due to milk loss and $63.8 \%$ was due to cost of treatment (Table-11). Total losses due to morbidity in bovines were INR 20, 689.50 in which milk yield loss and treatment cost constituted $28.7 \%$ and $71.29 \%$ of total cost, respectively.

Total economic losses due to HS in ND cattle were INR 37, 692.50, in which share of morbidity losses and mortality losses were $11.5 \%$ and $88.47 \%$, respectively. Per animal total losses in case of ND cattle was INR 2, 355.78. Total economic losses due to HS in CB cattle were INR 61, 342, in which share of morbidity losses and mortality losses were $7.48 \%$ and $92.51 \%$, respectively. Total economic loss per crossbred cattle was INR 3,228.52. In case of buffaloes, total economic losses due to HS were INR 2, 72, 805 in which share of morbidity losses and mortality losses were $4.30 \%$ and $95.69 \%$, respectively. Per buffalo economic loss was INR 4, 262.57. Total economic losses due to HS in sampled animals in study area were INR 3, 71, 839.50 , in which share of morbidity losses and mortality 
Table-12: Total economic losses due to HS. (INR)

\begin{tabular}{lcccc}
\hline Spp/Breed & Mortality loss(Rs) & Morbidity loss(Rs) & Total loss(Rs) & Total losses per animal(Rs) \\
\hline ND Cows & $33350(88.47)$ & $4342.5(11.5)$ & 37692.5 & 2355.78 \\
CB cows & $56750(92.51)$ & $4592(7.48)$ & 61342 & 3228.52 \\
Buffaloes & $261050(95.69)$ & $11755(4.30)$ & 272805 & 4262.57 \\
Total & $351150(94.43)$ & $20689.5(5.5)$ & 371839.5 & 3755.95 \\
\hline
\end{tabular}

Figures in brackets indicate percentages to the total loss.

Table-13: Mortality losses due to Surra. (INR)

\begin{tabular}{|c|c|c|c|c|c|c|}
\hline Spp/Breed & $\begin{array}{l}\text { Total No. } \\
\text { of died }\end{array}$ & $\begin{array}{l}\text { Mortality of } \\
\text { calves(Rs) }\end{array}$ & $\begin{array}{c}\text { Mortality of } \\
\text { young one (Rs) }\end{array}$ & $\begin{array}{l}\text { Mortality of } \\
\text { adult animal }\end{array}$ & $\begin{array}{c}\text { Treatment cost } \\
\text { (Rs) }\end{array}$ & $\begin{array}{l}\text { Total loss } \\
\text { (Rs) }\end{array}$ \\
\hline ND Cattle & 5 & $1500(2.3)$ & 0 & 60000 (92.87) & $3100(4.7)$ & 64600 \\
\hline CB Cattle & 5 & 0 & 30000 (24.24) & $90000(72.72)$ & 3750 (3.03) & 123750 \\
\hline Buffaloes & 8 & 0 & 30000 (16.10) & $150000(80.5)$ & $6220(3.34)$ & 186220 \\
\hline Total & 18 & $1500(0.4)$ & $60000(16.01)$ & 300000 (80.09) & $13070(3.48)$ & 374570 \\
\hline
\end{tabular}

Figures in brackets indicate percentages to the total loss.

Table-14: Morbidity losses due to Surra. (INR)

\begin{tabular}{lcccc}
\hline Spp/Breed & $\begin{array}{c}\text { Total No. of } \\
\text { recovered }\end{array}$ & $\begin{array}{c}\text { No. of lactating } \\
\text { animal }\end{array}$ & $\begin{array}{c}\text { Total milk loss } \\
\text { (Rs) }\end{array}$ & $\begin{array}{c}\text { Treatment cost } \\
\text { (Rs) }\end{array}$ \\
\hline ND Cattle & 17 & 9 & $520(6)$ & $8100(94)$ \\
CB Cattle & 18 & 10 & $7440(39.8)$ & 8620 \\
Buffaloes & 22 & 11 & $97350(88.5)$ & $11250(60.19)$ \\
Total & 57 & 30 & $105310(76.72)$ & $12600(11.4)$ \\
\hline
\end{tabular}

Figures in brackets indicate percentages to the total loss.

Table-15: Total economic losses due to Surra. (INR)

\begin{tabular}{lccc}
\hline Spp/Breed & Mortality loss(Rs) & Morbidity loss(Rs) & Total loss(Rs) \\
\hline ND Cows & $64600(88.22)$ & $8620(11.78)$ & 73220 \\
CB cows & $123750(86.87)$ & $18690(13.13)$ & 142440 \\
Buffaloes & $186220(62.87)$ & $109950(37.13)$ & 296170 \\
Total & $374570(73.18)$ & $137260(26.82)$ & 511830 \\
\hline
\end{tabular}

Figures in brackets indicate percentages to the total loss.

losses were $5.5 \%$ and $94.43 \%$ respec-tively (Table-12).

Economic losses due to surra: Mortality losses due to surra in nondescript cattle were INR 64, 600 in which share of mortality of calves and adult animal were $2.3 \%$ and $92.9 \%$, respectively. Treatment cost constituted $4.8 \%$ of total mortality loss. In case of crosssbred cattle, mortality losses were INR 1, 23, 750 in which share of mortality of young one, adult animal and treatment cost constituted $24.24 \%, 72.73 \%$ and $3.03 \%$, respectively (Table-13). Mortality losses in case of buffaloes were INR 1, 86, 220 in which proportionate contribution of young one, adult animals and cost of treatment were $16.1 \%, 80.5 \%$ and $3.4 \%$, respectively. Total mortality losses in bovines due to surra were INR 3, 74, 570 in which share of mortality of calves, young ones, adult animals and treatment cots were $0.4 \%, 16.01 \%, 80.09 \%$ and $3.5 \%$, respectively.

Morbidity losses due to surra in nondescript cattle were INR 8,620 , in which share of yield loss and treatment costs were $6 \%$ and $94 \%$, respectively. In case of crossbred cattle, morbidity losses were INR 18, 690, in which share of yield loss and treatment costs were $39.8 \%$ and $60.2 \%$, respectively (Table-14). Morbidity losses in buffaloes were INR 1, 09, 950 in which $88.5 \%$ was due to milk loss and $11.4 \%$ was due to cost of treatment. Total losses due to morbidity in bovines were INR 1, 37, 260 in which $76.72 \%$ was due to milk yield loss and $23.27 \%$ was due to cost of treatment.

Total economic losses due to Surra in ND cattle were INR 73, 220, in which share of morbidity losses and mortality losses were $11.78 \%$ and $88.22 \%$, respectively (Table-15). Per animal total losses in case of ND cattle was INR 3, 328. Total economic losses due to Surra in CB cattles were INR 1, 42, 440 in which share of morbidity losses and mortality losses were $13.12 \%$ and $86.87 \%$ respectively. Total economic losses per crossbred cattle were INR 6, 193. In case of buffaloes total economic losses due to Surra were INR 2, 96, 170 in which share of morbidity losses and mortality losses were $37.12 \%$ and $87 \%$, respectively. Per buffalo economic loss was INR 9, 872. Total economic losses due to surra in the study area were INR $5,11,830$, in which share of morbidity losses and mortality losses were $26.81 \%$ and $73.18 \%$, respectively.

\section{Conclusion}

The present study was carried out to analyze the factors associated with morbidity and mortality rates as well as to evaluate economic losses due to important diseases of bovines, viz. mastitis, HS and surra in Purvanchal Region of Uttar Pradesh. The findings of the study revealed that mastitis was more prevalent in high yielding $\mathrm{CB}$ cows than ND cows and buffaloes. Buffaloes were more susceptible to HS than cattle. The morbidity rates and case fatality rates were higher in 
calves due to HS in bovines. On the other hand, the morbidity rates and case fatality rates were higher in adults due to surra in bovines. Economic losses per lactation in bovines due to mastitis were highest in $\mathrm{CB}$ cows at INR $1,314.10$ per lactation. In case of ND cows and buffaloes total losses due to mastitis per lactation were INR 868.34 and INR 1, 272.36 respectively. Total economic losses due to HS in the study area were INR $3,71,839.50$, in which share of morbidity losses and mortality losses were $5.5 \%$ and $94.43 \%$, respectively Total losses due to HS per animal in ND cows, CB cows and buffaloes were INR 2, 355.78, INR 3, 228.52 and INR 4, 262.57, respectively. Total economic losses due to surra were INR 5, 11, 830, in which share of morbidity losses and mortality losses were $26.81 \%$ and $73.18 \%$, respectively. Total losses due to surra per animal in ND cows, CB cows and buffaloes were INR 3, 328.18, INR 6, 193 and INR 9, 872.33, respectively. The study thus revealed significant losses due to diseases in large ruminants on. There is thus ample scope for preventive measures to control the disease bovines. In this regard, there is need for sustained active surveillance programmes and development and use of novel diagnostics for early detection of the diseases so as preempt their adverse impact at the earliest.

\section{Authors' contributions}

DS was the Post Graduate Scholar of the division who carried out survey work, analyzed data and prepared the draft of the paper. SK was guide of DS, under whose supervision, the thesis was submitted. SK reviewed the manuscript and provided suggestions. BS helped in designing the study and approved the final format of the paper. DB carried out literature review, assisted in data analysis and drafted and reviewed the final manuscript. All the authors read and approved the final manuscript.

\section{Acknowledgements}

The authors are thankful to Joint Director of Research, Indian Veterinary Research Institute, India for providing facilities and fund for this study.

\section{Competing interests}

The authors declare that they have no competing interests.

\section{References}

1. McInerney, John (1996) Old economics for new problems livestock disease: Presidential address J Agril Econ. 47(3): 295-314.

2. Singh, B. and Prasad, S. (2008a) Modelling of economic losses due to some important diseases in goats in India, Agril. Econ. Res. Review, 21:297-302.

3. Singh, B. and Prasad, S. (2008b) Economic evaluation of important cattle diseases in India, Indian Vet J, 85(11): 120710.

4. Singh, R., Prasad. S. and Raghuvanshi, S. (2008) Economic evaluation of Mastitis in Bovine. In: Proceedings of $4^{\text {th }}$
Convocation of Indian Society of Veterinary Surgery, at Uttar Pradesh Pandit Deen Dayal Upadhyaya PashuChikitsa Vigyan Vishwavidyalaya evam Go-Anusandhan Sansthan (DUVASU), Mathura.

5. Singh, B., Prasad, S., Sinha, D.K. and Verma, M.R. (2013) Estimation of economic losses due to foot and mouth disease in India, Indian J Anim Sci, 83(9): 964-970.

6. Singh, R. (1997) On a model for estimating losses due to Foot and Mouth Disease in India, J. Indian Soc. Agril. Statistics, 50 (2): 135-143.

7. Singh, B. and Prasad, S. (2009) A model assessment of economic losses due to some important diseases in sheep in India. Indian J Anim Sci, 79(12): 1265-68.

8. El-Yuguda, A-D., Baba, S.S., Ambali, A.G. and Egwu, G.O. (2013) Seroprevalence of peste des petits ruminants among domestic, small and large ruminants in the semi-arid region of North-eastern Africa, Vet World, 6: 807-811.

9. Prabhu, M., Safiullah, A. and Md. Selvam, S. (2004) Evaluation of economic losses due to Foot and Mouth disease in bovines of Salem district, Agril. Econ. Res. Review, 17 (1): 77-84.

10. Shaheen, M.; Pampori, Z.A. and Shah, K.A. (2005) Studies on Foot and Mouth disease outbreaks in Kashmir, Indian Vet $J, 82: 1212-1213$.

11. Khan, M.I., Hussain, S.N., Bahadar, S., Ali, A. and Shah, I.A. (2008) An outbreak of peste des petits ruminants (PPR) in goats in district Chitral, N.W.F.P., Pakistan, ARPN Journal of Agricultural and Biological Science, 3(2): 19-22.

12. Census India. (2011) Office of Registrar General and Census Commissioner, Government of India, New Delhi.

13. Thirunavukkarasu, M. and Prabaharan, R. (1999) Impact of mastitis on dairy farms - An economic analysis, Cherion, 28(6): 188-194.

14. Singh, R. (2009). Economic appraisal of mastitis control programme in bovines. In: Proceedings of Winter School on 'Economic appraisal of livestock disease control projects', Indian Veterinary Research Institute, Izatnagar, $12^{\text {th }}$ Feb. $-4^{\text {th }}$ March, 2009. p36-38.

15. Sharma, P.C., Jindal, N., Shukla, C.L., Mata, M.M., Narang, G. And Khokhar, R.S. (2007) Epidemiological observations on Hemmorhagic Septicemia in Haryana state, Indian Vet. $J$, 84: $144-146$

16. Dua, K. (2001) Incidence, etiology and estimated economic losses due to mastitis in Punjab and in India: An update, Indian Dairyman, 53(10): 41-47.

17. de Alwis, M.C. (1981) Mortality among cattle and buffaloes in Sri Lanka due to Hemorrhagic septicemia, Trop Anim Health Prod, 13(4):195-202.

18. Verma, S., Mahajan, N.K. and Malik, G. (2004) An epidemiological study on bovine H.S. in Haryana, Indian $J$ Anim Res, 38(1): 14 -19.

19. Khan, A., Saddique, U. and Ahmad, R. (2006) Serosurveillance of Hemorrhagic septicemia in cattle and buffaloes in district Malakand, NWFP, Pakistan, J Agr Biol Sci, 1(4): 11-14.

20. Farooq, U., Saeed, Z. and Khan, M. (2011) Sero-surveillance of Hemorrhagic septicemia in cattle and buffaloes in district Dera-Ghazi-Khan, Punjab, Pakistan, Pak. Vet J, 31(3): 254 256.

21. Sasidhar, P.V.K., Reddy, Y.R. and Rao, B.S. (2002) Economics of mastitis, Indian J Anim Sci, 72 (6): 439-440.

22. Bardhan, D. (2013) Economic losses due to clinical mastitis in organized dairy farms, Indian J Dairy Sci, 66 (2): 168-172.

23. Ozsvari, L., Tilles, C.B., Fux, A. and Biro, O. (2003) The quantification of the economical losses caused by Staphylococcus aureus in a large-scale Holstein-Friesian dairy cattle farm, Acta-Agraria-Kaposvariensis. 7 (1): 1-8. 